\title{
The Enhancement of Hydroponic Plant Growth by Solar Energy
}

\author{
Fitria Hidayanti \\ Engineering Physics Department, Universitas Nasional, Jakarta 12520 Indonesia \\ fitriahidayanti@gmail.com
}

\begin{abstract}
Electrical energy is required in a hydroponic plant system. To increase the productivity of hydroponic plants, the LED Grow Light is used to help irradiate plant at night whereas this electrical energy is used for the pump of plant nutrient circulation and turn on the LED Grow Light. To overcome this problem, the approach taken is to utilize solar energy by turning it into electrical energy. The conversion of solar energy into electrical energy is known as Photovoltaic by using a device in the form of a solar cell. The hydroponic system used in this study is the Deep Flow Technique (DFT) hydroponic system. The circulation pump will be active every hour for 10 minutes while the LED Grow Light will turn on from 8 p.m. until 12 p.m. The average growth of plant height ranges from $0.8 \mathrm{~cm}$ to $1.5 \mathrm{~cm}$ per day and leaves growth of 1 to 2 pieces per day. Energy consumption of the circulating pump is 36.4 watt-hours per day for the overall hydroponic system.
\end{abstract}

Key words: Deep Flow Technique, Hydroponic, Solar Cell, LED Grow Light, Photovoltaic

\section{INTRODUCTION}

Electrical energy is needed in hydroponic agriculture. In remote areas, that are not electrified [1,2], the residents experience obstacles in developing hydroponic farming patterns because electrical energy is used to drive plant nutrient circulation pumps. Today, the conversion of energy to source electrical energy from various sources is a research concern [3-8].

Compliance of the large-scale electricity needs is the responsibility of the Government [9]. As individuals, we can only contribute to meet electricity needs on a small scale. The use of renewable energy in Indonesia is still very limited. In BP Statistic Review of World Energy 2018, it was stated that the consumption of renewable energy in Indonesia was very low, only $2.9 \%$ in 2017 , up $0.3 \%$ compared to consumption in 2016. Today the Government is currently promoting the use of renewable energy as their potentials is very large in Indonesia. One of the renewable energies that must be utilized is solar energy considering the amount of solar energy received by the earth surface is around $3 \times 10^{24}$ joule per year. This energy is equivalent to $2 \times 10^{17}$ Watt. When calculated, this amount is 10,000 times the energy consumption in the whole world [10]. Nevertheless, the use of electricity in Indonesia is not evenly distributed, especially in remote and rural areas so that solar cell device such as monocrystalline $[11,12]$ and polycrystalline modules $[13,14]$ are needed to help the hydroponic system especially in driving the nutrient circulation pump $[15,16]$.

\section{Photovoltaic Effect Mechanism}

As a study of [17-21], the physical mechanism of photon conversion (Figure 1) into electric current through several stages below:

a. Photon absorption. Photons hit the device must be maximally absorbed. Therefore, a material used must be transparent and have a very small reflection coefficient.

b. Exciton formation. Exciton is formed in the active site of solar cells after absorbing photons.

c. Diffusion and migration of excitons. The formed exciton will move along the material through diffusion and migration.

d. Exciton dissociation. Exciton will dissociate into hole and electron pairs.

e. Charges transport. The dissociated electrons and holes will move towards the appropriate electrode (metal). Electrons will go to electrodes which have a lower working function and holes towards electrodes with a higher working function.

f. Collection of charges. Electrons and holes that can reach the electrode will cause a photon current.

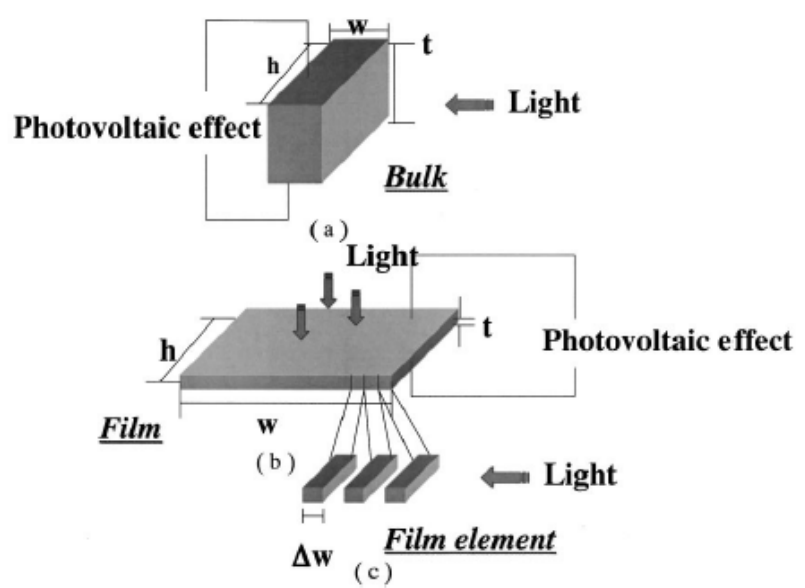

Figure 1: Photovoltaic Effect on to (a) bulk, (b) film, and (c) film element of photovoltaic material [21] 
Fitria Hidayanti, International Journal of Emerging Trends in Engineering Research, 8(9), September 2020, 5699 - 5703

\section{Solar Cell}

Electrons are charged particles that are capable of being influenced by the electric field. The presence of an electric field on an electron can cause electrons to move. This is done on $\mathrm{p}-\mathrm{n}$ junction solar cells by producing an electric field on the $\mathrm{p}-\mathrm{n}$ junction so that electrons can flow due to the presence of the electric field. When the semiconductor p-n junction is illuminated, electron and hole in semiconductor will be released. The release of both charge carrier results in the addition of electric field strength in the depletion area. These charges excess will cause the charge moving because of the electric field in the depletion area. In this situation, the drift current is greater than the diffusion current. Therefore it results in a drift current that is the current generated due to the appearance of the electric field. Then this current is used by the p-n junction solar cell as an electric current [22-25].

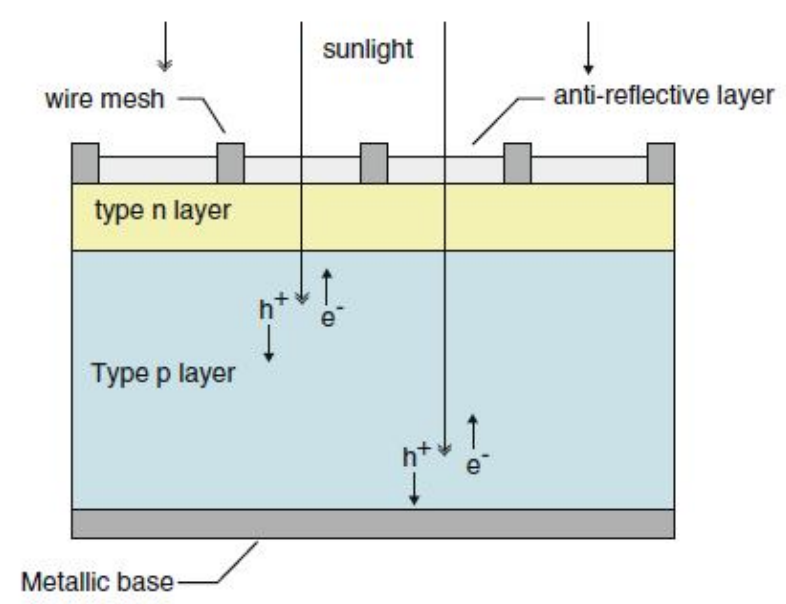

Figure 2: Schematic Representation of Solar Cell [26]

The phenomenon of the release of electrons and the formation of holes when the semiconductor $\mathrm{p}-\mathrm{n}$ junction is illuminated by light and the p-n junction semiconductor energy diagram is shown on Figure 2.

\section{Hydroponics System}

Hydroponics is the cultivation of plants by utilizing water without using soil in emphasizing the fulfilment of nutrient needs for plants. Several hydroponic planting methods are:

a. Nutrient Film Technique (NFT) Hydroponic, is a cultivation model by placing plant roots in a shallow water layer. The water is circulated and contains nutrients according to plant needs [27, 28].

b. Deep Flow Technique (DFT) Hydroponics, the principle is almost the same as NFT, except that the DFT gutters are installed flat and the height of nutrient solution flowed is $8 \mathrm{~cm} \mathrm{[27,29].}$

c. Ebb and Flow Hydroponics, where plants are placed in a batch that contains planting media, nutrients will be given alternately between flowing and no flowing nutrient with a maximum time limit without solution during 10 minutes [30-33].

\section{MATERIALS AND METHODS}

The research method of Solar Hydroponic System Design is depicted in the following flowchart (Figure 3):

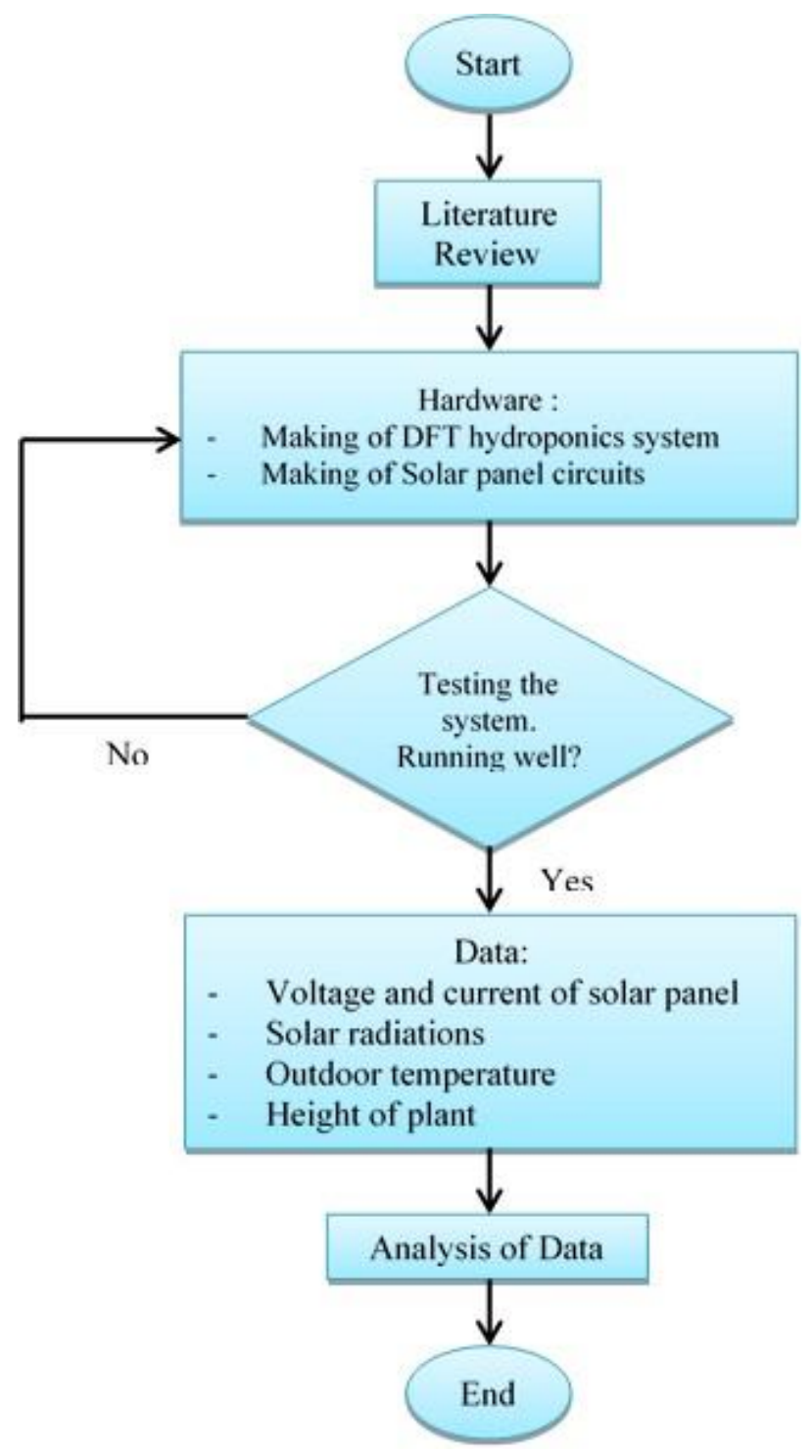

Figure 3: Flowchart of Research

The scheme for solar hydroponic design systems is shown in Figure 4 below.

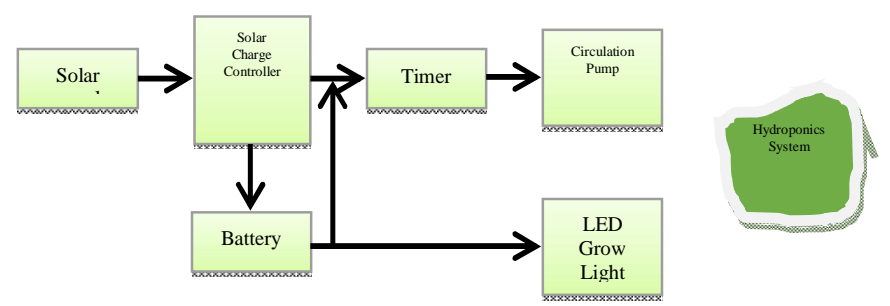

Figure 4: Scheme for Design Systems 
The data taken are voltage and the current system, outdoor temperature, solar radiation and plant height. Data collection is carried out starting at 7 a.m. until 6 p.m. This goal is solar energy absorbed by solar cells would have a maximum intensity and focus on the growth of a plant. The addition of the LED Grow Light component is expected to replace sunlight at night so that it can accelerate plant growth. The testing of solar cells performance will be displayed in a graph that shows the relationship between current and voltage system from the solar panel.

\section{RESULTS AND DISCUSSION}

\section{Testing of Hydroponics System}

This research using the Deep Flow Technique (DFT) hydroponic system where the hydroponic tray is mounted horizontally (Figure 5). Liquid nutrient in the reservoir is pumped and flowed into the hydroponic tray. LED Grow Light placed on the upper tray. This light turned on from 8 p.m. until 12 p.m., while the circulation pump will be active every hour for 10 minutes. The growth of plants irradiated by LED Grow Light is faster than those not exposed to LED Grow Light, with an average growth from $0.8 \mathrm{~cm}$ to $1.5 \mathrm{~cm}$ per day and leaves growth of 1 to 2 pieces per day.
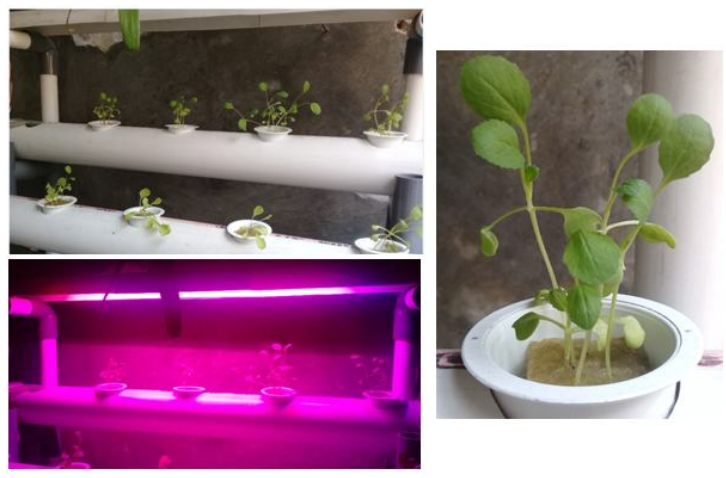

Figure 5: DFT Hydrophonic System

The solar panel used is a monocrystalline type with a maximum power of 10WP. Hydroponic circulation pump has a $12 \mathrm{~V}$ DC voltage specification, with 4.2 watts of power, while the LED Grow Light has 7 watts of power. Data collection is carried out for three days, starting at 7 a.m. until 6 p.m. An overview of weather conditions when retrieving data can be seen in Figure 6 and Figure 7.

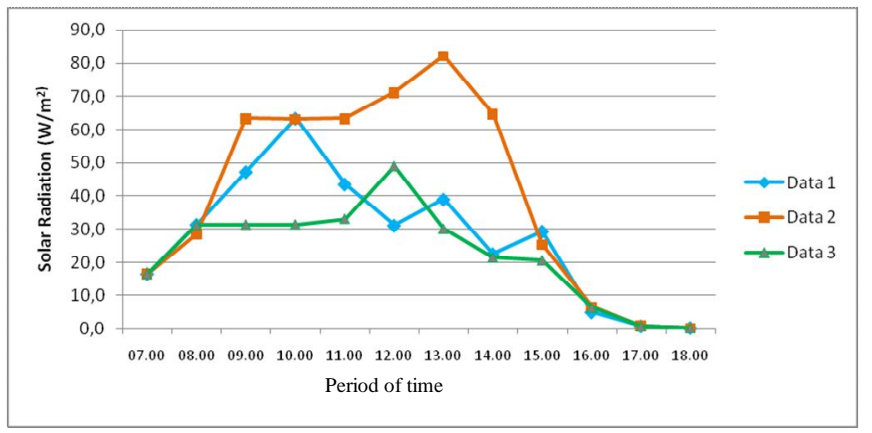

Figure 6: Variation of Solar Radiation on the Period of Time
The weather when taking data- 1 tends to be unstable where sunlight suddenly dims and then bright again. Ideally, at 12 a.m., the position of the sun is exactly above and has a huge intensity, but in this condition, the intensity is only 31.1 $\mathrm{W} / \mathrm{m}^{2}$.

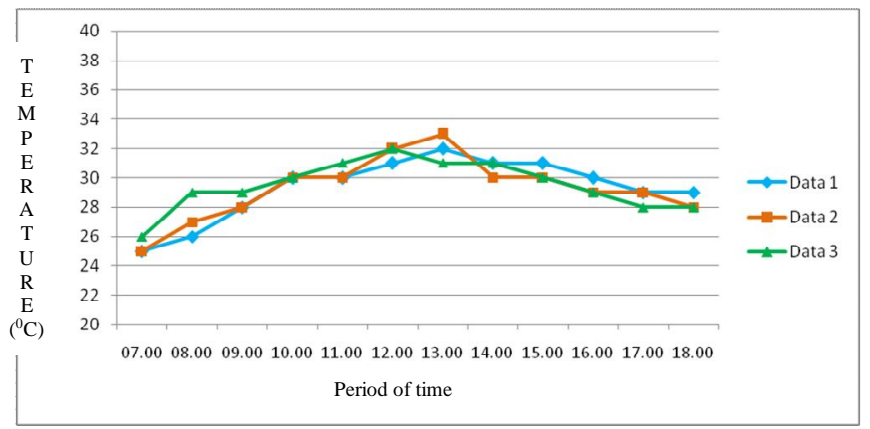

Figure 7: Variation of Outdoor Temperature on Period of Time

\section{Measurement of Voltage and Current of Solar Panel}

Figure 8 shows the relationship of voltage and the current system as a function of time. The maximum voltage on data-1 is $19.3 \mathrm{~V}$, while on data- 2 is $19.5 \mathrm{~V}$ and data- 3 is $19.8 \mathrm{~V}$. The maximum current on data- 1 is $0.37 \mathrm{~A}$, while data- 2 is $0.35 \mathrm{~A}$, and data- 3 is $0.30 \mathrm{~A}$.

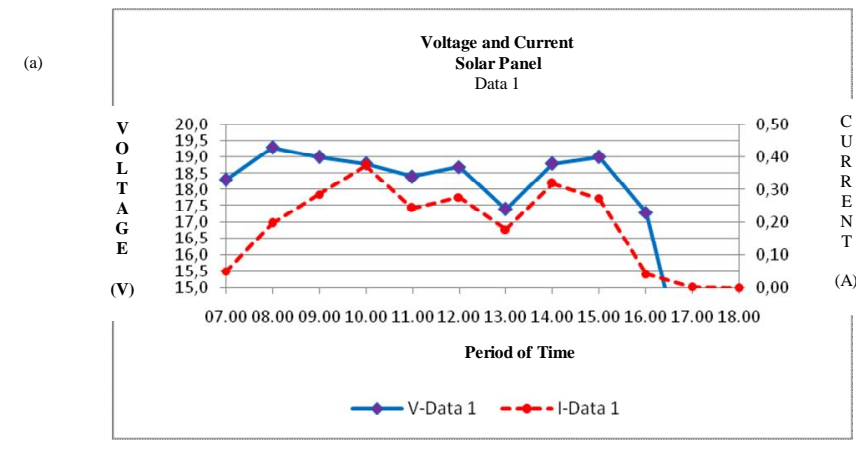

(b)

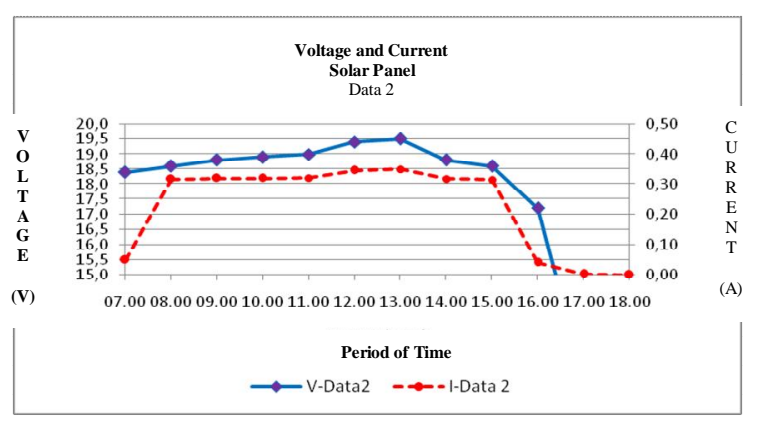

(c)

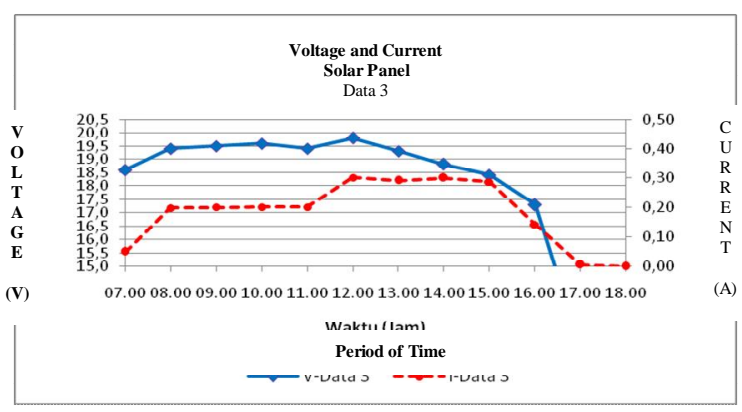

Figure 8: Relationship of Voltage and Current System on Period of Time (a) Data 1, (b) Data 2, and (c) Data 3 
Based on the calculation of electricity need for circulation pumps was obtained electricity needs per day was 8.4 watt-hours for 4.2-watt pumping power during 2 operational hours and 28 watt-hours for 7-watt pumping power during 4 operational hours, therefore, the energy consumption of the circulating pump is 36.4 watt-hours per day for the overall hydroponic system.

\section{CONCLUSION}

In summary, this research designed a Deep Flow Technique (DFT) hydroponic system. Average growth from $0.8 \mathrm{~cm}$ to 1.5 $\mathrm{cm}$ per day and leaves growth of 1 to 2 pieces per day. Energy consumption of the circulating pump is 36.4 watt-hours per day for the overall hydroponic system.

\section{ACKNOWLEDGEMENT}

Thank you for Lembaga Penelitian dan Pengabdian kepada Masyarakat (LPPM) Universitas Nasional and my colleagues at Faculty of Engineering and Science, Universitas Nasional, Jakarta, Indonesia.

\section{REFERENCES}

1. Omer, A. M. Environmental and socio-economic aspects of possible development in renewable energy use. Journal of Agricultural Extension and Rural Development. 2(1). 001-021, 2010.

2. Bundschuh, J., and Chen, G. (Eds.). Sustainable energy solutions in agriculture. CRC Press. 2014.

3. Hidayanti F., Wati E.K., and Miftahudin M. F. Design of Energy Harvesters on Motorcycle Exhaust using Thermoelectric Generator for Power Supply Electronic Device. International Journal of Renewable Energy Research. 10(1), 251 - 259. 2020.

4. Hidayanti F., Wati E.K., and Akbar H. Energy Harvesting System Design for Converting Noise into Electrical Energy. International Journal of Advanced Science and Technology. 29(03), 4791 - 4802. 2020.

5. Hidayanti F., Rahmah F., and Wiryawan A. Design of Motorcycle Security System with Fingerprint Sensor using Arduino Uno Microcontroller. International Journal of Advanced Science and Technology. 29(05), 4374 - 4391. 2020.

6. Hidayanti F., Santoso H. H., and Amalia D. Induction Measurement of Extra High Voltage Air Duct. International Journal of Emerging Trends in Engineering Research. 8(4), 1424 - 1427. 2020.

7. Hidayanti F., Extraction of Limonite Nickel Ore of Tanjung Buli, Halmahera by Coal Roasting and Acid Leaching. International Journal of Mechanical and Production Engineering Research and Development. 10(2), 513 - 522, 2020.

8. Hidayanti F., Development of Mercury Film Electrode for Cadmium Ion Determination using
Voltammetry. International Journal of Advanced Science and Technology. 29(03), 5156 - 5163, 2020.

9. Kaygusuz, K. Energy for sustainable development: A case of developing countries. Renewable and Sustainable Energy Reviews. 16(2). 1116-1126, 2012.

10. Global, B.P., BP statistical review of world energy June 2017. Relatório. Disponível em: http://www.bp.com/en/global/corporate/energy-econom ics/statistical-review-of-world-energy.html. 2017.

11. Bahabry, R. R., Kutbee, A. T., Khan, S. M., Sepulveda, A. C., Wicaksono, I., Nour, M., ... and Syed, A., Solar Cells: Corrugation Architecture Enabled Ultraflexible Wafer $\square$ Scale High $\square$ Efficiency Monocrystalline Silicon Solar Cell. (Adv. Energy Mater. 12/2018). Advanced Energy Materials. 8(12): p. 1870055, 2018.

12. Hashmi, G., et al., Study of the enhancement of the efficiency of the monocrystalline silicon solar cell by optimizing effective parameters using PC1D simulation". Silicon, p. 1-8, 2018.

13. Saga, T., Advances in crystalline silicon solar cell technology for industrial mass production. npg asia materials. 2(3): p. 96, 2010.

14. Gordon, I., Carnel, L., Van Gestel, D., Beaucarne, G., and Poortmans, J., $8 \%$ Efficient thin $\square$ film polycrystalline $\square$ silicon solar cells based on aluminum $\square$ induced crystallization and thermal CVD. Progress in Photovoltaics: Research and Applications, 15(7): p. 575-586, 2007.

15. Hidayanti F., Rahmah F., and Sahro A. Mockup as Internet of Things Application for Hydroponics Plant Monitoring System. International Journal of Advanced Science and Technology. 29(05), 5157 - 5164. 2020.

16. Hidayanti F., Rahmah F., and Septratama S. Design of Single-Axis Solar Tracker based on Arduino Uno Microcontroller. International Journal of Emerging Trends in Engineering Research. 8(4), 983 - 986, 2020.

17. Messenger, R.A. and A. Abtahi, Photovoltaic systems engineering. CRC press. 2010.

18. Luque, A. and S. Hegedus, Handbook of photovoltaic science and engineering. John Wiley \& Sons. 2011.

19. Fthenakis, V.M. and P.A. Lynn, Electricity from Sunlight". Photovoltaic-systems Integration and Sustainability. John Wiley \& Sons. 2018.

20. Jamil, M., M. Rizwan, and D.P. Kothari, Grid Integration of Solar Photovoltaic Systems. CRC Press. 2017.

21. Ichiki, M., Maeda, R., Morikawa, Y., Mabune, Y., Nakada, T., and Nonaka, K., Photovoltaic effect of lead lanthanum zirconate titanate in a layered film structure design. Applied physics letters. 84(3): p. 395-397, 2004.

22. Hidayanti F., Rahmah F., and Agusto J. Design of Solar Tracker on Solar Panel with Fresnel Concentrator. International Journal of Advanced Science and Technology. 29(05), 1014 - 1025. 2020.

23. Hidayanti F., Lestari, K. R., and Liyanto A. Triple-junction solar cell modelling simulation using the PC1D application. International Journal of 
Fitria Hidayanti, International Journal of Emerging Trends in Engineering Research, 8(9), September 2020, 5699 - 5703

Emerging Trends in Engineering Research. 8(8), 4666 4670, 2020.

24. Callister, W.D. and D.G. Rethwisch. Materials science and engineering: an introduction. John wiley \& sons New York, Vol. 7. 2007.

25. Kitai, A., Principles of Solar Cells, LEDs and Diodes: The role of the PN junction. John Wiley \& Sons. 2011.

26. Cardona, A.J.A., C.A.P. Chica, and D.H.O. Barragán, Building-Integrated Photovoltaic Systems (BIPVS): Performance and Modeling Under Outdoor Conditions. Springer. 2018.

27. Al-Tawaha, A.R., et al., Effect of water flow rate on quantity and quality of lettuce (Lactuca sativa L.) in nutrient film technique (NFT) under hydroponics conditions. Bulgarian Journal of Agricultural Science, 24(5): p. 791-798, 2018.

28. Mohammed, S., Introduction to Nutrient Film Technique, in Tomorrow's Agriculture. Springer. p. 7-11, 2018.

29. Chrysargyris, A., Petropoulos, S. A., Fernandes, Â., Barros, L., Tzortzakis, N., and Ferreira, I. C., Effect of phosphorus application rate on Mentha spicata $L$. grown in deep flow technique (DFT). Food chemistry, 276: p. 84-92, 2019.

30. Song, W., Zhou, L., Yang, C., Cao, X., Zhang, L., and Liu, X., Tomato Fusarium wilt and its chemical control strategies in a hydroponic system. Crop protection. 23(3): p. 243-247, 2004.

31. Hidayanti F., Rahmah F., and Ikrimah M. Dual-Axis Solar Tracking System Efficiency for Hydroponics Pump. International Journal of Emerging Trends in Engineering Research. 8(6), 2631 - 2634. 2020.

32. Hidayanti F., The Effect of Monocrystalline and Polycrystalline Material Structure on Solar Cell Performance. International Journal of Emerging Trends in Engineering Research. 8(7), 3420 - 3427. 2020.

33. Hidayanti F., Performance of Portable Battery Charger of Monocrystalline Solar Panel. International Journal of Emerging Trends in Engineering Research. 8(7), 3181 - 3184. 2020. 